\title{
PALEOCOLOGIC POSITION OF ORTHOPHRAGMINIDS
}

COSOVIC, Vlasta, MARJANAC, Tihomir. Division of Geology \& Paleontology, Faculty of Science, Zvonimirova 8, 10000 Zagreb, CROATIA

Middle Eocene limestones of eastern Adriatic Coast (Croatia) were deposited just before drowning of Adriatic carbonate platform(s) and deposition of Tertiary flysch. The uppermost part of Foraminiferal Limestone contains orbitoidal macroforaminifers (ORT) eg Discocyclina which may form the bulk of the rock. The foraminifers inhabited transitional carbonate platform-slope environments; despite their abundance and cosmopolitan distribution, very little paleoecologic literature is available. It is generally accepted they lived in subtropic to tropic seas at "greater" depths (less that $200 \mathrm{~m}$ by our data). They were symbiont-bearing forms which recycled nutrients, adapted to oligotrophic environment. Orthophraminids have no Recent relatives.

We have interpreted the paleoecologic conditions in four sections on the Istrian Peninsula. Nummulitids, sphaerogypsinids, some rotaliids, ORT, and planktonic foraminifers were analyzed quantitatively; sedimentological characteristics and processes controlling distributions of Recent foraminifers were also considered. Problems involved were: different fossilization potential of the various forms; and difficulty of identification in randomly-oriented thin sections. Data were plotted on a triangular diagram: planktonic foraminifers and large flat ORT at the apex; large lenticular nummulitids and spherical sphaerogypsinids to the left; and smaller rotaliids to the right. The ratios are taken to indicate water depth. Two localities show good clustering, one shows bipartite clustering, and one, large scatter. The last suggests shallowest water (foreslope to open shelf) and the first two, toe of the slope (but not below lower photic zone).

The test morphology of ORT was compared with that of nummulitids, assuming that similar morphology indicates the same environments, as indicated by habitat or Recent relatives of nummulitids. The abundance of ORT was compared to sphaerogypsinids, lenticularids and planktonic foraminifers, respectively. Globular ORT are in the shallowest water and flat ORT in the deepest. Foraminifers and nanofossils suggest that the shallowest of the four sections studied is also the oldest. 